\title{
IN VITRO ANTIOXIDANT ACTIVITY AND GC-MS ANALYSIS OF THE ETHANOLIC EXTRACTS OF TERMINALIA BELLERICA ROXB (BAHEDA)
}

\author{
RASNA GUPTA, RAM LAKHAN SINGH*, NEERAJA DWIVEDI1
}

Nutraceutical Laboratory, Department of Biochemistry, Dr. Ram Manohar Lohia Avadh University, Faizabad 224001, U. P., India, 1Department of Biotechnology, IFTM University, Moradabad 244102, U. P., India

Email: drrlsingh@rediffmail.com

Received: 18 Jul 2016 Revised and Accepted: 21 Sep 2016

ABSTRACT

Objective: To investigate the antioxidant activity of ethanolic extract of Terminalia bellerica fruit pulp (TBFP), seed (TBS) and bark (TBB), and identification of phytochemical constituents of said extracts.

Methods: The antioxidant potential of T. bellerica (TB) parts was evaluated by free radical scavenging activity (FRSA), superoxide anion radical scavenging activity (SARSA), hydroxyl radical scavenging activity (HRSA) and compared with reference standard quercetin. Lipid peroxidation (LPO), ferric thiocyanate activity (FTC) and reducing power (RP) of the plant extracts were also examined. The phytochemical constituents of said extracts have been quantified by gas chromatography-mass spectrometer (GC-MS) method.

Results: Ethanolic extract of TBFP exhibited high phenolic content (254.33) followed by TBS (227.33) and TBB (185) mg/g of GAE. TBFP showed lowest $\mathrm{IC}_{50}$ for FRSA $(62 \mu \mathrm{g} / \mathrm{ml})$, SARSA $(39 \mu \mathrm{g} / \mathrm{ml})$ and HRSA $(27 \mu \mathrm{g} / \mathrm{ml})$ and highest RP (3.39 ascorbic acid equivalents/ml). TBB showed lowest IC 50 for LPO $(48 \mu \mathrm{g} / \mathrm{ml})$ whereas TBS showed lowest IC 50 for FTC $(109 \mu \mathrm{g} / \mathrm{ml})$. Predominant phyto-compounds present in TB extracts were quinic acid, gallic acid, ethyl galate, 9, 12 octadecadienoic acid and glucopyranose in varying concentrations as analyzed by GC-MS.

Conclusion: On the basis of correlation of antioxidant studies with total phenolic content (TPC) and GC-MS analysis of different part of TB, it may be concluded that high concentration of total phenolics and other bioactive phytochemicals of TB extracts make it a potential source of nutraceutical antioxidants.

Keywords: Reactive oxygen species, Antioxidant, GC-MS, Phenolics, Phytochemicals

(c) 2016 The Authors. Published by Innovare Academic Sciences Pvt Ltd. This is an open access article under the CC BY license (http://creativecommons.org/licenses/by/4. 0/) DOI: http://dx.doi.org/10.22159/ijpps.2016v8i11.14175

\section{INTRODUCTION}

Terminalia bellerica (TB) Roxb (Combretaceae), is a large deciduous tree and is commonly known as beleric mycobalane. It has been valued in Ayurvedic and traditional system of medicine for treatment of wide range of diseases having many pharmacological properties such as immunomodulatory, anti-inflammatory, anticancer, hepatoprotective and antimicrobial activities [1-5]. It is an integral part of the traditional laxative formulation, Triphala which is used for a variety of ailments in Ayurvedic medicines since ancient times. Fruits of TB are purgative, analgesic, anthelmintic and antipyretic, and are also useful in bronchitis, asthma, dyspepsia, piles, diarrhea and cough. Ethanolic extract of TB fruits was reported to enhance glucose uptake over the control group of rats in various muscles cell lines e. g. Vero, L6 and 3T3 [6]. Methanolic extract of TB bark has shown thrombolytic and cytotoxic activities in human blood [7]. Leaf extracts of TB showed promising free radical scavenging activity with inhibitory concentration $\mathrm{IC}_{50}$, (concentration of a drug that is needed for $50 \%$ inhibition in vitro) of $58 \mu \mathrm{g} / \mathrm{ml}$ [8]. The seed oil is utilized to cure skin diseases, premature graying of hair and can be applied on painful swollen parts. Overall, TB enhances the body resistance against diseases and is used as herbal medicine to get remedies from all the above ailments [9].

Oxidative stresses occur when the concentration of reactive oxygen species (ROS) increases to a level that exceeds the cell's defense capacity. ROS involves both free radicals as superoxide $\left(\mathrm{O}_{2}{ }^{\bullet}\right)$, hydroxyl $\left(\mathrm{OH}^{\bullet}\right)$, per hydroxy $\left(\mathrm{HO}_{2}{ }^{\circ}\right)$ and alkoxy (RO') radicals and non-radical molecules such as hydrogen peroxide $\left(\mathrm{H}_{2} \mathrm{O}_{2}\right)$ and singlet oxygen $\left({ }^{1} \mathrm{O}_{2}\right)$. ROS are produced either extracellular in the normal metabolism of mammalians cells by NADPH-oxidase, myeloperoxidase and nitric oxide synthase enzymes or intracellular as a byproduct of metabolic processes. The controlled generation of ROS in the extracellular space was developed evolutionarily as part of the innate immune response against bacteria and other pathogens However, excessive release of ROS may also induce deleterious effects; causing damage to host DNA, RNA, proteins and lipids which ultimately result in oxidative stress $[10,11]$. Thus oxidative stress is an imbalance situation between oxidants and antioxidants potentially leading to cell damage. It is believed to significantly contribute to the development of a number of diseases like cancers, liver injury, cardiovascular and age-related diseases [12]

Many synthetic antioxidants are currently in use that may cause cellular toxicity, however, there is a growing consumer preference for natural antioxidants because of their good efficacy and lower toxicity. Natural antioxidants have the capacity to improve medicinal values of plants, and acts as nutraceuticals to terminate free radical chain reactions in biological systems, thus may provide additional health benefits to consumers [13]. T. bellerica, having shown the potential to cure many diseases, is a fit case for investigation of its phytochemicals which impart antioxidant activity to this plant. The present study has been planned to explore the antioxidant potential of ethanolic extracts of TB fruit pulp, seed and bark along with quantification of important biomolecules in these parts using GC-MS technique. These experiments are expected to provide an insight in to the scientific basis of the healing potential of TB.

\section{MATERIALS AND METHODS}

Plant materials

Plant materials were collected from herbal garden of Narendra Dev University of Agriculture and Technology Kumarganj, Faizabad, U. P., India and identified with the help of Dr. MN Srivastava, Senior Scientist, Botany Division, CSIR-Central Drug Research Institute, Lucknow, India and the voucher specimens (2322 CSIR-CDRI) were submitted in CDRI herbarium. 


\section{Chemicals and reagents}

Quercetin, gallic acid, 1, 1-diphenyl-2-picrylhydrazyl (DPPH) and thiobarbituric acid (TBA) were purchased from Sigma-Aldrich, St. Louis, USA. Ascorbic acid, Folin Ciocalteau's phenol reagents were the product of E. Merk, Mumbai, India. Nitro blue tetrazolium (NBT), phenazine methosulphate (PMS), reduced nicotinamide adenine dinucleotide $(\mathrm{NADH})$, potassium ferricyanide, trichloroacetic acid (TCA), ferric chloride $\left(\mathrm{FeCl}_{3}\right)$, ferrous sulphate $\left(\mathrm{FeSO}_{4}\right.$ ) and sodium dodecyl sulphate (SDS) were purchased from SRL India. All other reagents and chemicals used were of analytical grade.

\section{Extraction procedure}

Twenty grams of the dried and powdered plant sample of T. bellerica fruit pulp (TBFP), seed (TBS) and bark (TBB) were extracted with $70 \%$ ethanolic solvent (in distilled water) for overnight at room temperature in an orbital shaker. The extracts were separated from the residues by filtering through Whatman No. 1 filter paper. The residues were extracted until discoloration with the same fresh solvent and extracts combined. The combined extracts were concentrated and freed of solvent under reduced pressure at $40{ }^{\circ} \mathrm{C}$ by using a rotary evaporator and lyophilized till dryness. The dried crude concentrated extracts were stored at $-4{ }^{\circ} \mathrm{C}$ and used for the antioxidant activity determination and GC-MS analysis.

\section{Antioxidant studies \\ Total phenolic content (TPC)}

TPC of powdered plant material was extracted with 50\% methanol $+1 \% \mathrm{HCl}$, filtered and made up to $10 \mathrm{ml}$ each with water. TPC was measured with the method of Ragazzi and Veronese [14]. To $0.1 \mathrm{ml}$ plant extract, $0.5 \mathrm{ml}$ of Folin's reagent $(1 \mathrm{~N})$ and $1.0 \mathrm{ml}$ of sodium carbonate were added subsequently. The test mixture was mixed properly and kept at room temperature for $30 \mathrm{~min}$ and volume was made up to $12.5 \mathrm{ml}$ with distilled water. The absorbance of this solution was measured at $720 \mathrm{~nm}$. The TPC was reported as $\mathrm{mg}$ of gallic acid equivalent (GAE)/g of dry weight.

\section{Free radical scavenging activity (FRSA)}

FRSA of the extracts was measured by using DPPH stable radical according to the method of Yen and Duh [15]. Each extract $(0.1 \mathrm{ml})$ was added to freshly prepared DPPH solution $\left(6 \times 10^{-5} \mathrm{M}\right.$ in HPLC grade $2.9 \mathrm{ml}$ methanol) and mixed vigorously. The reduction of the DPPH radical was measured by continuous monitoring of the decrease in absorbance at $515 \mathrm{~nm}$ until a stable value was obtained.

\section{Inhibition $(\%)=[($ blank absorbance-sample absorbance $) /$ blank} absorbance] $\times 100$

The $\mathrm{IC}_{50}$ which represents the amount of antioxidant necessary to decrease the initial DPPH concentration by $50 \%$, representing a parameter widely used to measure the antioxidant activity, was calculated from a calibration curve by linear regression.

\section{Superoxide anion radical scavenging activity (SARSA)}

This assay was based on the capacity of the extract to inhibit the reduction of NBT by the method of Nishikimi et al. [16]. Three milliliters reaction mixture containing a different aliquot of plant extracts $(50,100,150$ and $200 \mu \mathrm{l})$ with $0.1 \mathrm{M}$ phosphate buffer $(\mathrm{pH}$ 7.8), $60 \mu \mathrm{M}$ PMS, $468 \mu \mathrm{M}$ NADH and $150 \mu \mathrm{M}$ NBT was incubated for $5 \mathrm{~min}$ at ambient temperature. Absorbance was read after $6 \mathrm{~min}$ at $560 \mathrm{~nm}$ using UV-Vis spectrophotometer. The percentage inhibition of $\mathrm{O}_{2} \bullet$ generation was measured by comparing the absorbance of the control and those of the reaction mixture containing test sample.

\section{Reducing power (RP)}

RP of the extracts was determined by using a slightly modified method of ferric reducing antioxidant power assay [17]. Each extract $(1.0 \mathrm{ml})$ was mixed with $2.5 \mathrm{ml}$ of phosphate buffer $(0.1 \mathrm{M}, \mathrm{pH} 6.6)$ and $2.5 \mathrm{ml}$ of $1 \%(\mathrm{w} / \mathrm{v})$ potassium ferricyanide and was incubated at $50{ }^{\circ} \mathrm{C}$ for $20 \mathrm{~min}$. After completion of the incubation period, $2.5 \mathrm{ml}$ of $10 \%(\mathrm{w} / \mathrm{v})$ TCA was added to terminate the reaction. The upper layer $(2.5 \mathrm{ml})$ was diluted with equal volume of deionized water. Finally, $0.5 \mathrm{ml}$ of $0.1 \%(\mathrm{w} / \mathrm{v}) \mathrm{FeCl}_{3}$ was added and after $10 \mathrm{~min}$ the absorbance was measured at $700 \mathrm{~nm}$ against a blank. RP was expressed as ascorbic acid equivalents $(1 \mathrm{ASE}=1 \mathrm{mmol}$ ascorbic acid). ASE value is inversely proportional to RP.

\section{Lipid peroxidation (LPO)}

A modified thiobarbituric acid-reactive species (TBARS) assay method of Ohkawa et al. [18] was applied to measure the LPO formation, using egg homogenate as lipid rich media. Egg homogenate $(10 \%$ in $0.2 \mathrm{M}$ PBS, $0.5 \mathrm{ml})$, test extract $(0.1 \mathrm{ml})$ and distilled water $(0.85 \mathrm{ml})$ were mixed in a test tube. Finally, $\mathrm{FeSO}_{4}$ $(0.07 \mathrm{M}, 0.05 \mathrm{ml})$ was added to the reaction mixture and incubated at $37^{\circ} \mathrm{C}$ temperature for $30 \mathrm{~min}$ to induce LPO. Thereafter, acetic acid $(20 \%, 1.5 \mathrm{ml})$, TBA $(0.8 \%$ prepared in $1.1 \%$ SDS, $1.5 \mathrm{ml})$ and TCA $(20 \%, 0.05 \mathrm{ml})$ were added, vortexed and then heated in a boiling water bath for $60 \mathrm{~min}$. After cooling, butanol $(5 \mathrm{ml})$ was added to each tube and centrifuged for $10 \mathrm{~min}$ at $3000 \mathrm{rpm}$. The absorbance of the upper organic layer was measured at $532 \mathrm{~nm}$ by UV-Vis spectrophotometer (Labtronics, model LT-2910).

\section{Hydroxyl radical scavenging activity (HRSA)}

Hydroxyl radicals were generated by a mixture of $\mathrm{Fe}^{3+}$-EDTA, $\mathrm{H}_{2} \mathrm{O}_{2}$ and ascorbic acid and, scavenging activity was assessed by monitoring the degraded fragments of deoxyribose, through malondialdehyde (MDA) formation [19]. The reaction mixtures contained ascorbic acid $(50 \mu \mathrm{M}), \mathrm{FeCl}_{3}(20 \mu \mathrm{M})$, EDTA (2 mmol), $\mathrm{H}_{2} \mathrm{O}_{2} \quad(1.42 \mathrm{mmol})$, deoxyribose $(2.8 \mathrm{mmol})$ with different concentrations of the plant extracts in a final volume of $1 \mathrm{ml}$, was incubated at $37{ }^{\circ} \mathrm{C}$ for 1 hour and then $1 \mathrm{ml}$ of $2.8 \%$ TCA (w/v in water) and $1 \mathrm{ml}$ of $1 \%$ TBA (w/v) were added. The mixture was heated in a boiling water bath for $30 \mathrm{~min}$. It was cooled and absorbance was taken at $532 \mathrm{~nm}$.

\section{Ferric thiocyanate assay (FTC)}

The reaction mixture containing $400 \mu \mathrm{l}$ of different concentration of ethanolic plant extracts, $200 \mu \mathrm{l}$ of diluted linoleic acid $(25 \mathrm{mg} / \mathrm{ml}$ in $99 \%$ ethanol) and $400 \mu \mathrm{l}$ of $50 \mathrm{mmol}$ phosphate buffer ( $\mathrm{pH} 7.4)$ was incubated for $15 \mathrm{~min}$ at $40{ }^{\circ} \mathrm{C}$. A $100 \mu \mathrm{l}$ aliquot of this was then mixed with a reaction mixture containing $3 \mathrm{ml}$ of $70 \%$ ethanol, 100 $\mu \mathrm{l}$ of ammonium thiocyanate $(300 \mathrm{mg} / \mathrm{ml}$ in distilled water $)$ and 100 $\mu \mathrm{l}$ of $\mathrm{FeSO}_{4}$. Red color developed was measured at $535 \mathrm{~nm}$ [20].

\section{Gas chromatography-mass spectrometry (GC-MS)}

Plant samples were further processed for GC-MS (Trace GC ultra TSQ quantum XLS mass spectrometer, Thermo, USA) analysis [21] to identify bioactive phytoconstituents responsible for antioxidant activity. Interpretation on mass-spectrum was conducted using the database of the National Institute of Standards and Technology (NIST). The spectrum of the unknown components was compared with the spectrum of known components stored in the NIST library.

\section{Statistical analysis}

All analytical data are subjected to an analysis of variance (ANOVA). Each value is mean \pm standard deviation (SD) of three replications $(n=3)$. Statistical analysis was conducted by using prism software (graph pad prism software version 3.0, USA). The results obtained were considered statistically significant if the $p<0.05$. The $R^{2}$ value and the regression equation were calculated by plotting a graph showing the total phenolic content on the $\mathrm{x}$-axis and the antioxidant deciding parameters on the y-axis, using MS office excel 2007.

\section{RESULTS}

\section{Total phenolic content}

Phenolic compounds may contribute directly to antioxidant potential $[22,23]$. Therefore, it would be worthwhile to determine the TPC of TB extracts. The TPC in TBFP, TBS and TBB was 254.33, 227.33 and $185 \mathrm{mg} / \mathrm{g}$ of GAE (fig. 1). The highest value of TPC in TBFP showed its high antioxidant potential than TBS and TBB.

\section{Free radical scavenging activity}

TBFP, TBS and TBB extracts were examined for their potential to scavenge free radicals and measured as percentage inhibition. TBFP was considered to be most potent significant free radical scavenger 
than TBS and TBB and its value of inhibition ranged from 31.66 to $84.16 \%$ in a concentration-dependent manner $(50-200 \mu \mathrm{g} / \mathrm{ml})$ (fig. 2). FRSA values were in following order TBFP $(84.16 \%)>\mathrm{TBS}$ $(81.45 \%)>\mathrm{TBB}(75.62 \%)$ in comparison to standard quercetin $(90.25 \%)$. The IC 50 value of TBFP was $62 \mu \mathrm{g} / \mathrm{ml}$ whereas, in the case of TBS and TBB, it was 73 and $106 \mu \mathrm{g} / \mathrm{ml}$, respectively.

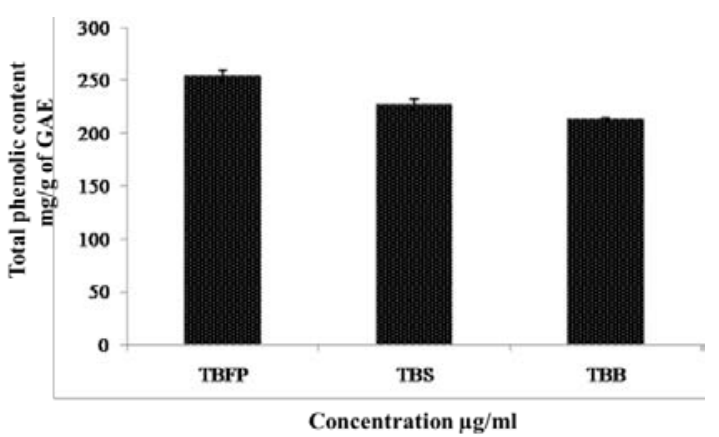

Fig. 1: Total phenolic content of ethanolic extracts of $T$. bellerica fruit pulp (TBFP), seed (TBS), bark (TBB). Values are mean \pm SD of three replications $(n=3)$

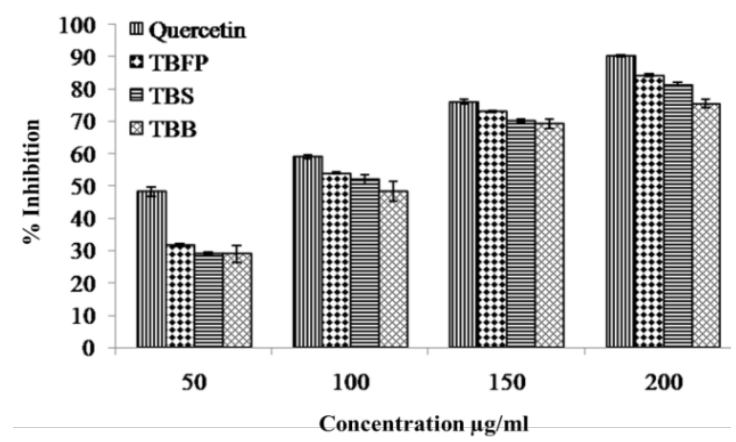

Fig. 2: Free radical scavenging activity of $T$. bellerica fruit pulp (TBFP), seed (TBS), bark (TBB) and standard quercetin against DPPH radicals at varying concentrations. Values are mean $\pm S D$ of three replications $(n=3)$

\section{Superoxide anion radical scavenging activity}

The antioxidant potential of TBFP, TBS and TBB was considered to be significant in comparison to the reference standard quercetin. The result presented in fig. 3 shows that TBFP and TBB extracts inhibits NBT reduction significantly higher than TBS. The TBFP extract inhibited production of $\mathrm{O}_{2} \cdot$ by $20.69,39.40,61.50$ and $78.39 \%$, respectively when $50,100,150,200 \mu \mathrm{g} / \mathrm{ml}$ of extract were used in the reaction. The order of SARSA was TBFP $(78.39 \%)>$ TBB $(77.14 \%)>$ TBS (71.51\%) in comparison to standard quercetin (91.77\%).

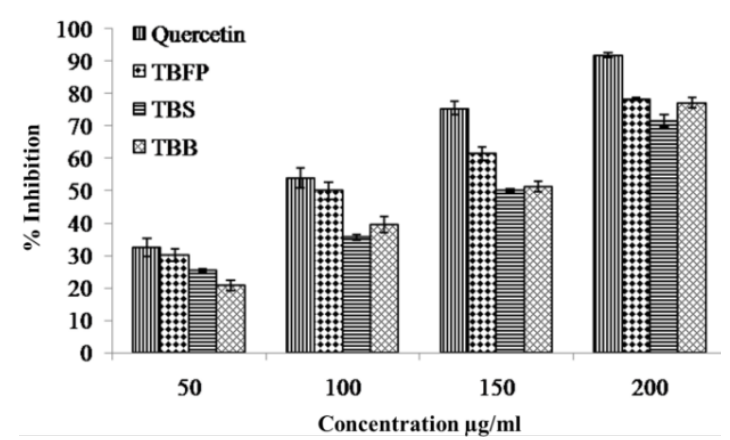

Fig. 3: Inhibitory effects of ethanolic extracts of $T$. bellerica fruit pulp (TBFP), seed (TBS), bark (TBB) and standard quercetin on superoxide anion radical at varying concentrations. Values are mean \pm SD of three replications $(n=3)$

\section{Reducing power}

The RP of a compound may act as a significant indicator of its potential antioxidant activity [24]. With regards to RP, higher reducing capacity might be attributed to the higher amount of phenolic compounds. TBFP had significantly high $\mathrm{Fe}^{3+}$ to $\mathrm{Fe}^{2+}$ transformation capacity (3.39) than TBS (5.02) and TBB (5.12) in comparison to standard quercetin (1.12) ASE/ml (fig. 4) showing high phenolic content in TBFP.

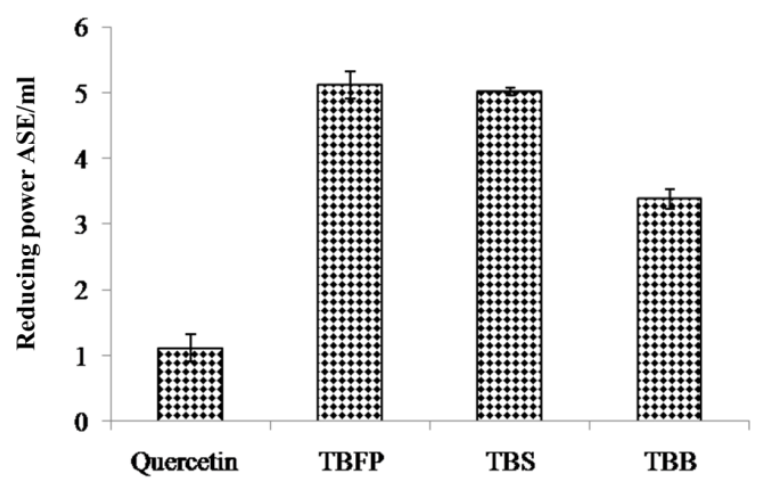

Fig. 4: Reducing power (ASE/ml) of ethanolic extracts of $T$. bellerica fruit pulp (TBFP), seed (TBS), bark (TBB) and standard quercetin. Values are mean $\pm S D$ of three replications $(n=3)$

\section{Lipid peroxidation}

Studies on the inhibition of LPO in the presence of extracts were carried out and expressed as percent inhibition. The TBFP, TBS and TBB extracts prevent LPO induced by $\mathrm{FeSO} 4$ and percentage inhibition varied from 74.36 to $84.41 \%$, respectively. Maximum LPO inhibition was shown by TBFP than TBS and TBB in a concentration dependent manner at $100-400 \mu \mathrm{g} / \mathrm{ml}$ in comparison to standard (95.39\%). Antioxidant potential was in the order of TBFP>TBB $>$ TBS (fig. 5).

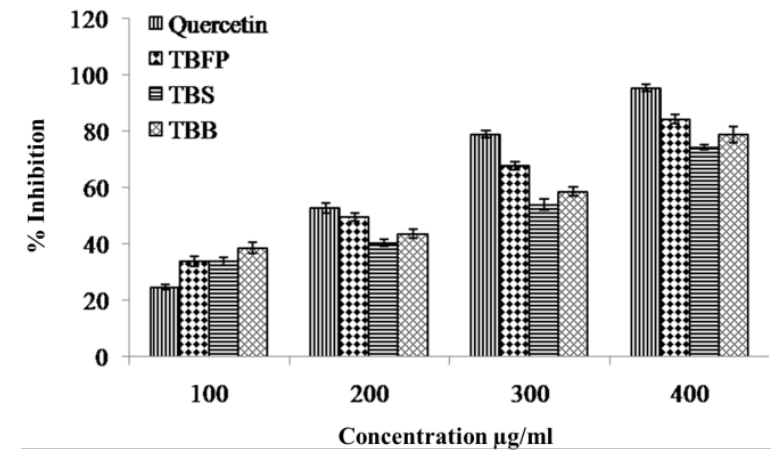

Fig. 5: Inhibitory effects of ethanolic extracts of $T$. bellerica fruit pulp (TBFP), seed (TBS), bark (TBB) and standard quercetin on LPO using egg homogenate as a lipid-rich source at varying concentrations. Values are mean $\pm S D$ of three replications $(n=3)$

\section{Hydroxyl radical scavenging activity}

TB extracts were further studied for their ability to chelate iron and/or to scavenge $\mathrm{OH} \cdot$ by using deoxyribose degradation assay. The TBFP was found to be most potent $\mathrm{OH}^{\bullet}$ scavenger with inhibition of 40.46 to $78.87 \%$ in increasing extracts concentration (50-200 $\mu \mathrm{g} / \mathrm{ml})$ in comparison with quercetin $(91.12 \%)$. The biochemical studies revealed that TBFP, TBS and TBB caused a concentrationdependent inhibition of deoxyribose oxidation. Based on their inhibitory potential the order of $\mathrm{OH}$ •scavenging was as follows; TBFP $>$ TBB $>$ TBS (fig. 6). 


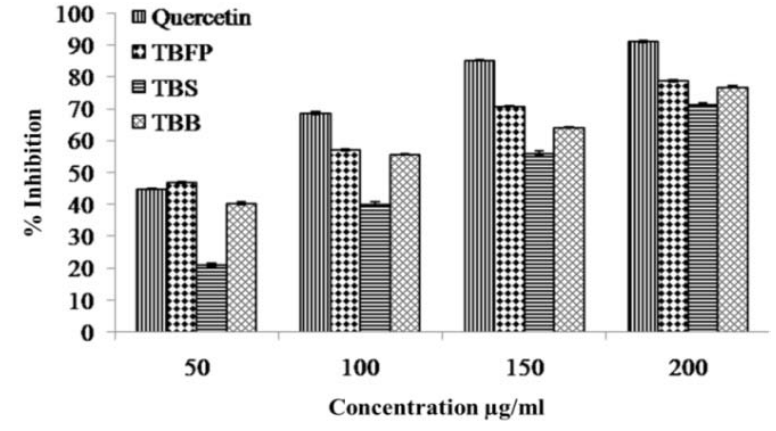

Fig. 6: Inhibitory effects of ethanolic extracts of $T$. bellerica fruit pulp (TBFP), seed (TBS), bark (TBB) and standard quercetin on hydroxyl radical mediated deoxyribose degradation at varying concentrations. Values are mean $\pm S D$ of three replications $(n=3)$

\section{Ferric thiocyanate assay}

In tested extracts, TBS showed maximum inhibition (83.19\%) than TBFP $(80.19 \%)$ and TBB $(79.90 \%)$ to inhibit production of free radicals which initiate oxidation of lipids and proteins. Quercetin showed $92.12 \%$ inhibition to inhibit production of peroxides. The inhibition is increased with increasing concentration of the extracts from 50 to $200 \mu \mathrm{g} / \mathrm{ml}$ in the reaction mixture (fig. 7).

\section{GC-MS analysis}

In order to find out phytoconstituents responsible for the antioxidant activity, GC-MS analysis of the TB extracts was conducted. GC-MS chromatogram showed the presence of 8 peaks in TBFP, 12 in TBS and 13 in TBB (fig. 8). Mass spectra of the detected compounds were compared with the already available spectra with NIST library and the phyto-compounds were characterized and identified (table 1). Of all identified compounds in TB extracts, the most prevailing compounds were: quinic acid (chlorogenic acid), gallic acid, ethyl galate, 9, 12 octadecadienoic acid and glucopyranose.

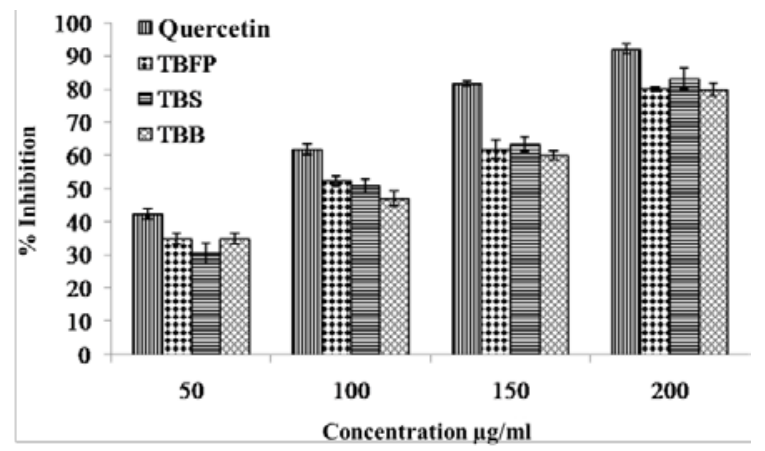

Fig. 7: Inhibitory effects of ethanolic extract of $T$. bellerica fruit pulp (TBFP), seed (TBS), bark (TBB) and standard quercetin on ferric ion chelation by ferric thiocyanate assay method at varying concentrations. Values are mean $\pm S D$ of three replications $(n=3)$

Correlation between total phenolic content and antioxidant activity

Phenolics are the major contributors to the antioxidant activity. The correlation between TPC and FRSA of different plant extracts had a correlation coefficient of $\mathrm{R}^{2}=0.9935$ ( $\mathrm{y}=0.1245 \mathrm{x}+52.751$ ) (fig. 9 a.). A good correlation also exists in between TPC and SARSA $\left(\mathrm{R}^{2}=0.9501\right)$ LPO $\left(\mathrm{R}^{2}=0.9662\right)$ and HRSA $\left(\mathrm{R}^{2}=0.9788\right)$ (fig. $\left.9 \mathrm{~b}, \mathrm{c}, \mathrm{d}\right)$ whereas FTC assay showed less correlation $\left(\mathrm{R}^{2}=0.8795\right)$ with TPC (fig. $\left.9 \mathrm{e}\right)$.
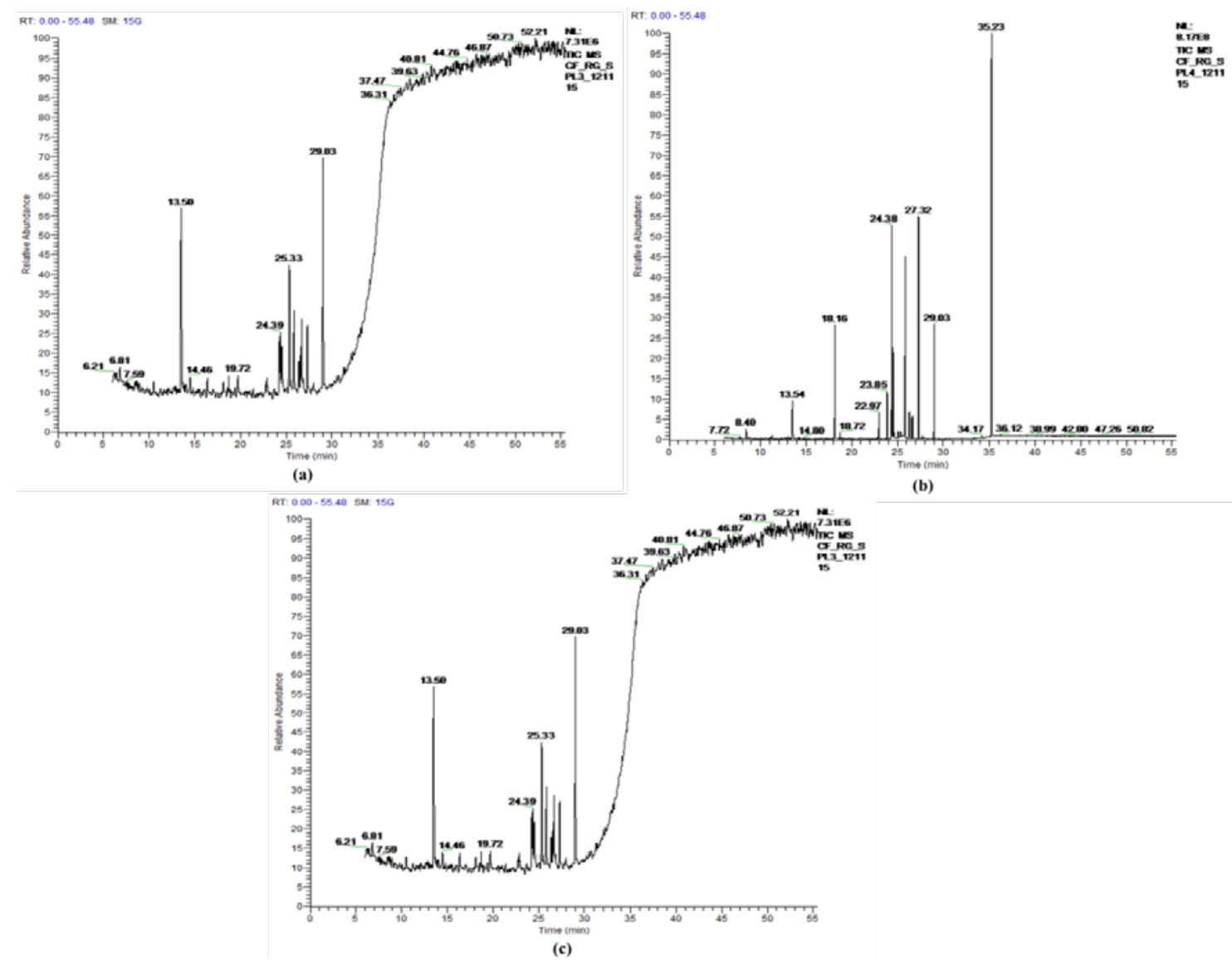

Fig. 8: GC-MS chromatogram of ethanolic extracts of $T$. bellerica (TB). (a) fruit pulp (TBFP); (b) seed (TBS); (c) bark (TBB) 
Table 1: Compounds found in real samples by GC-MS as per NIST library

\begin{tabular}{|c|c|c|c|c|c|}
\hline S. No. & RT & Compound name & $\begin{array}{l}\text { Peak area } \\
\text { Percentage (\%) }\end{array}$ & MW & $\begin{array}{l}\text { Fragmentation pattern values } \\
(\mathrm{m} / \mathrm{z})\end{array}$ \\
\hline \multicolumn{6}{|c|}{ T. bellerica fruit pulp } \\
\hline 1 & 13.50 & $\begin{array}{l}\text { Methyl 7-(2,4,6 trimethylphenyl)-5H furo } \\
(2,3 \text { c)thiopyran-4-corboxylate }\end{array}$ & 24.85 & 314 & $299,300,301,314,315$ \\
\hline 2 & 24.39 & D-fructose $1,3,4,5,6$ pentakis-0-(trimethylsilyl) & 5.44 & 540 & $73,204,217,437,447$ \\
\hline 3 & 25.33 & Quinic acid & 6.75 & 552 & $73,147,255,345,346$ \\
\hline 4 & 25.85 & Glucopyranose & 6.14 & 540 & $73,147,191,204,205$ \\
\hline 5 & 26.36 & $3,4,5$ trimethoxy benzoic acid ethyl ester & 29.8 & 414 & $45,73,281,282,414$ \\
\hline 6 & 26.69 & $3,4,5$ tris (trimethylsiloxyl) benzoic acid & 12.52 & 458 & $73,281,447,458,459$ \\
\hline 7 & 27.33 & Glucopyranose & 3.86 & 540 & $73,147,191,204,205$ \\
\hline 8 & 29.03 & Inositol-TMS & 10.63 & 612 & $7,147,217,305,318$ \\
\hline \multicolumn{6}{|c|}{ T. bellerica seed } \\
\hline 1 & 13.54 & Silanol-trimethyl phosphate & 5.14 & 314 & $73,299,300,301$ \\
\hline 2 & 18.16 & 9,12 Octadecadienoic acid & 7.94 & 442 & $41,55,67,91,105$ \\
\hline 3 & 22.97 & 9,12 Octadecadienoic acid & 1.01 & 442 & $41,55,67,91,105$ \\
\hline 4 & 23.85 & $\begin{array}{l}\text { 3,4,5 Tris (trimethylsiloxyl)-1-cyclohexene-1-corboxylic } \\
\text { acid }\end{array}$ & 3.48 & 462 & $73,204,255,357,372$ \\
\hline 5 & 24.38 & Hexopyranose 1,2,3,4,6 pentakis-0-trimethylsilyl & 12.41 & 540 & $73,147,191,204,217$ \\
\hline 6 & 25.85 & Alfa-D-Galactopyranose & 15.28 & 420 & $73,75,117,147,191$ \\
\hline 7 & 26.31 & Quinic acid & 1.96 & 552 & $73,147,255,345,346$ \\
\hline 8 & 26.56 & Alfa-D-galactopyranose & 1.43 & 420 & $73,75,117,147,151$ \\
\hline 9 & 26.69 & 3,4,5-trihydroxy benzoic acid ethyl ester & 0.93 & 414 & $45,73,281,282$ \\
\hline 10 & 27.32 & L-fructose-trimethylsilyl ether & 16.44 & 452 & $73,147,191,204,205$ \\
\hline 11 & 29.03 & Ethyl galate & 9.07 & 198 & $125,153,154,170,198$ \\
\hline 12 & 35.23 & D-fructose $1,3,4,5,6$ pentakis-O-(trimethylsilyl) & 24.93 & 540 & $73,204,217,437,447$ \\
\hline \multicolumn{6}{|c|}{ T. bellerica bark } \\
\hline 1 & 13.5 & 3,7-Dioxa-2,8-disilanone & 23.95 & 308 & $73,103,117,147,205$ \\
\hline 2 & 18.13 & L-mallic acid-O-trimethylsilyl & 0.86 & 350 & $73,133,147,233,245$ \\
\hline 3 & 19.72 & D-Xylopyranose & 1.44 & 438 & $73,147,191,204,217$ \\
\hline 4 & 24.26 & D-Xylofuranose & 3.89 & 230 & $43,59,100,129,215$ \\
\hline 5 & 24.38 & D-fructose $1,3,4,5,6$ pentakis-O-(trimethylsilyl) & 3.04 & 540 & $73,147,204,217,437$ \\
\hline 6 & 24.52 & Galactopyranose & 2.84 & 540 & $73,191,204,205,217$ \\
\hline 7 & 25.33 & Acrylic acid 2,3 bis-trimethylsilyl-ester & 12.38 & 320 & $45,73,147,221,305$ \\
\hline 8 & 25.85 & Benzoic acid 3,4,5 tristrimethylsilyl ester & 7.75 & 458 & $73,281,447,458,459$ \\
\hline 9 & 26.37 & Glucopyranose & 2.97 & 540 & $73,147,191,204,205$ \\
\hline 10 & 26.56 & Inositol 1,2,3,4,5,6-hexakis-0-trimethylsilyl & 2.59 & 612 & $73,147,217,305,318$ \\
\hline 11 & 26.7 & D-fructose $1,3,4,5,6$ pentakis-O-(trimethylsilyl) & 5.51 & 540 & $73,147,204,217,361$ \\
\hline 12 & 27.33 & Glucopyranose & 6.78 & 540 & $73,143,191,204,205$ \\
\hline 13 & 29.03 & Inositol & 26.01 & 612 & $73,147,191,217,305$ \\
\hline
\end{tabular}

RT: retention time; MW: molecular weight

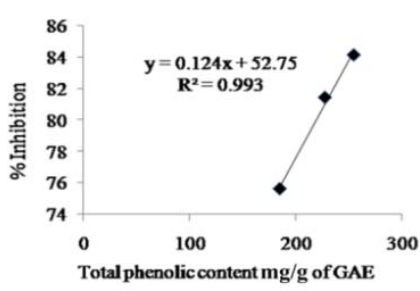

(a)

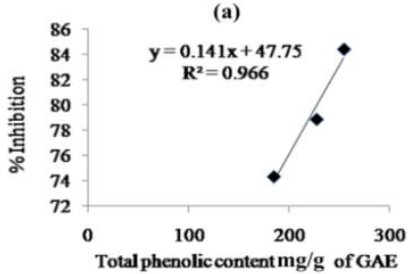

(c)

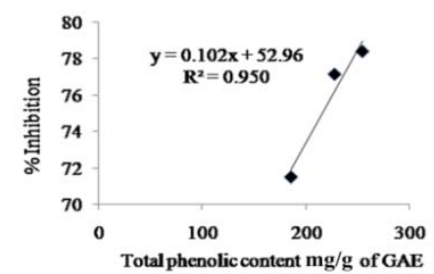

(b)

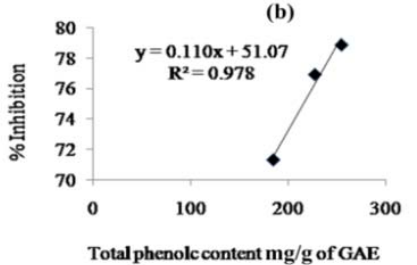

(d)

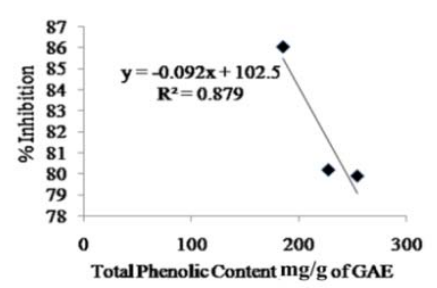

(e)

Fig. 9: Linear correlation between TPC ( $x$ axis) in the plant extracts in relation to their antioxidant activity (y axis). (a) TPC versus FRSA; (b) TPC versus SARSA; (c) TPC versus LPO; (d) TPC versus HRSA; (e) TPC versus FTC assay 


\section{DISCUSSION}

Recently, phenolic compounds received considerable attention for their effective antioxidant properties, and their beneficial effects are attributed to their RP and FRSA affinity [22]. Plants are good sources of phenolic compounds. Therefore, the plant which contains a high concentration of phenolic compounds could be a good source of natural antioxidant. Numerous investigations of the antioxidant activity of plant extracts confirmed a linear correlation between the total phenolic content and particular antioxidant activity [25]. In earlier studies, the TPC in methanolic and acetone extracts of TB fruits were reported as 108.692 and $186.288 \mathrm{mg} / \mathrm{g}$ GAE [26[, respectively, which is lower than the ethanolic extract values reported by us. This is in agreement with a study by Taso and Deng [27] which showed that phenolic compounds are generally better extracted by using alcoholic solvents.

DPPH is a stable nitrogen-centered, lipophilic free radical widely used in evaluating antioxidant activities in a relatively short time compared to some other methods. The odd electron in DPPH becomes paired with hydrogen from a free radical scavenging antioxidant to form reduced DPPH-H. The resultant decolorization from purple to yellow can be detected spectrophotometrically at $517 \mathrm{~nm}$. We have already reported that TB leaf inhibits $\mathrm{DPPH}^{*}$ radical at $\mathrm{IC}_{50}$ of $58 \mu \mathrm{g} / \mathrm{ml}$ [8]. These results were in agreement with earlier findings where methanolic extracts of TB fruits significantly suppressed free radicals at $\mathrm{IC}_{50}$ of $213.11 \mu \mathrm{g} / \mathrm{ml}$ [26]. Singhal et al. [28] and Venkatalakshmi et al. [29] reported that aqueous extract of TB bark and Terminalia catappa had $35.29 \%$ and $30.71 \%$ scavenging potential to $\mathrm{DPPH}^{*}$ radical at 200 and $250 \mu \mathrm{g} / \mathrm{ml}$ which was lower than the value reported by us in ethanolic extract showing superiority of the ethanolic extraction process.

The $\mathrm{O}_{2} \cdot$ is primary ROS among the free radicals and is often associated with the regulation of inflammatory pathways. SARSA of TB extracts was studied by using a non-enzymatic method known as PMS-NADH-NBT reduction system. In this method, $\mathrm{O}_{2} \bullet$-derived from dissolved oxygen by PMS-NADH coupling reaction reduces the yellow dye $\left(\mathrm{NBT}^{2+}\right)$ to produce the blue formazan, which was measured spectrophotometrically at $560 \mathrm{~nm}$. It was found that plant samples containing antioxidant molecules are able to inhibit the formation of blue formazan complex [30,31]. The decrease in absorbance at $560 \mathrm{~nm}$ with plant extract indicates the consumption of $\mathrm{O}_{2} *$ in the reaction mixture. Earlier studies showed SARSA of aqueous extracts of TB fruits at $\mathrm{IC}_{50}$ of $892.85 \mu \mathrm{g} / \mathrm{ml}$ [32] which is very high in comparison to $\mathrm{IC}_{50}$ of ethanolic extract TBFP $(39 \mu \mathrm{g} / \mathrm{ml})$ and TBS $(92 \mu \mathrm{g} / \mathrm{ml})$ reported by us. Venkatalakshmi et al. [29] showed an aqueous extract of T. catappa bark had $63.46 \% \mathrm{O}_{2}$. scavenging potential at $1000 \mu \mathrm{g} / \mathrm{ml}$ whereas ethanolic extract had $77.14 \%$ at $200 \mu \mathrm{g} / \mathrm{ml}$ reported by us.

RP was measured by direct electron donation in the reduction of $\mathrm{Fe}^{3+}(\mathrm{CN}-)_{6}-\mathrm{Fe}^{2+}(\mathrm{CN}-)_{6}$ to reduce ferricyanide to ferrocyanide, which then reacts with $\mathrm{FeCl}_{3}$ to form blue colored complex (Perl's Prussian blue) $\left(\mathrm{Fe}^{3+}\right)_{4}\left[\mathrm{Fe}^{2+}(\mathrm{CN})_{6}\right]_{3}$ that was measured at $700 \mathrm{~nm}$. Depending on the reducing ability of tested extracts, the yellow colour of test solution changes to various shades of green or blue [33]. Earlier study by Tupe et al. [34] showed the strong RP potential of methanolic extracts of Terminalia chebula fruit (4.29) and Terminalia arjuna bark (4.26), which is in agreement with the present study. Our data on the RP of the tested extracts suggested that it is such as to contribute significantly towards the observed antioxidant effect of TB in comparison to standard quercetin.

LPO is an oxidative degradation of polyunsaturated fatty acids present in the biological membranes which produce a variety of secondary products including several aldehydes such as malondialdehyde (MDA). MDA may react with adenine and guanine in DNA, forming DNA adducts which may be mutagenic [35]. The production of this aldehyde is used as a biomarker to measure the level of oxidative stress in an organism [36]. According to past research finding aqueous fruit extract of Terminalia chebula exhibited anti-LPO activity at IC $\mathrm{I}_{50}$ of $163 \mu \mathrm{g} / \mathrm{ml}$ [37] in comparison to our reported IC 50 values of TBFP $(51 \mu \mathrm{g} / \mathrm{ml})$ and TBS $(60 \mu \mathrm{g} / \mathrm{ml})$. On the basis of reported studies, it may be concluded that ethanolic extracts of TB had significantly high potential to inhibit initiation and progression of LPO in membranes. The high anti-LPO activity of TBFP may be attributed to the high content of phenolic compounds. Therefore, the inhibition of LPO could be caused by the chelation of $\mathrm{Fe}^{2+}$ or by trapping of free radicals $[8,36]$.

The $\mathrm{OH} \cdot$ is the nonspecific mediator of many of the oxidative damage to cells and are involved in various neurodegenerative and cardiovascular diseases [38]. HRSA of plant extracts was determined by its ability to compete with deoxyribose for $\mathrm{OH}^{\bullet}$. In this assay, 2deoxy-2-ribose was oxidized when exposed to $\mathrm{OH}^{\bullet}$ generated by the fenton-type reaction. The oxidative degradation can be detected by heating the products with TBA under acidic conditions to develop a pink chromogen (thiobarbituric acid reactive species) with a maximum absorbance at $532 \mathrm{~nm}$ [39]. Tested extracts compete with deoxyribose and diminish chromogen formation in a dosedependent response. Hazra et al. [25] reported that the $\mathrm{IC}_{50}$ of methanolic extract of TB fruit that inhibits 50\% DNA damage was $203.25 \mu \mathrm{g} / \mathrm{ml}$, which is much higher in comparison to ethanolic extract IC 50 of TBFP $(27 \mu \mathrm{g} / \mathrm{ml})$ and TBS $(58 \mu \mathrm{g} / \mathrm{ml})$. Based on these scientific data we can conclude that ethanolic extracts of TB plant parts contain potent compounds that may have a better capability of reducing free radical induced DNA damage.

FTC assay is used to assess the production of peroxides at the initial stage of oxidation, while TBA test is used to measure the secondary products of oxidation such as aldehydes and ketones. The advantage of using ammonium thiocyanate over other coloring reagents is that the specific binding of thiocyanate ion to iron only. Our results with ammonium thiocyanate experiments showed that the TBS extract is an active scavenger of $\mathrm{Fe}^{3+}$ ion which is in agreement with the work done on known natural $\mathrm{Fe}^{3+}$ scavengers $[8,24,36]$. In this method, the concentration of peroxide decreases as the antioxidant potential of plant extract increases.

To identify the responsible phytochemicals for antioxidant potential of TB extracts, we further carried out GC-MS analysis of fruit pulp, seed, and bark of TB. Quinic acid (chlorogenic acid), gallic acid, ethyl galate, 9, 12 octadecadienoic acid and glucopyranose were found to be most abundant compounds in TB extracts. They were designated by comparing their MS spectra to those of standard spectra from the NIST library. Gallic acid (3, 4, 5-trihydroxybenzoic acid), a naturally occurring low molecular weight tri phenolic compound, has emerged as a strong antioxidant and an efficient apoptosis inducing agent [40]. Gallic acid has been reported to have antimutagenic, antioxidant, anti-inflammatory, antitumor, anticancer and apoptotic properties [41, 42]. Gallic acid derivatives such as ethyl galate have also been found in a number of phytomedicines with antioxidant, apoptotic and anticancer activities [43]. Reported studies on the biological function of gallic acid and its derivatives show that it is a versatile natural antioxidant with promising therapeutic and industrial applications. In plant extracts, quinic acid can occur as an ester with caffeic acid, forming chlorogenic acid, a major component in coffee. Quinic acid is known to induce nutritional efficiency of aromatic amino acids that might be responsible for its antioxidant activity [44]. TBS extract is a rich source of essential fatty acids linoleic and linolenic $(9,12$ octadecadienoic acid) that play a very important role in the formation of lipid raft during cell signaling. Earlier studies by Amala and Jeyaraj [45] on GC-MS analysis revealed the presence of various phytochemical compounds in $95 \%$ methanolic fruit extracts of TB. These findings suggest that TB plant is a rich source of many bioactive phyto compounds with significant antioxidant activity.

It is a known fact that phenolic compounds are potential antioxidants and free radical scavengers; hence, there should be a close correlation between the content of phenolic compounds and antioxidant activity [46]. The correlation coefficient $\left(\mathrm{R}^{2}\right)$ between TPC and FRSA $\left(\mathrm{R}^{2}=0.99\right)$ suggests that $99 \%$ of the antioxidant capacity of plant extracts results from the contribution of the phenolic compounds. Also, only $1 \%$ of the activity is attributable to non-phenolic compounds. Activity may also come from the presence of other antioxidant secondary metabolites such as volatiles oils, terpenes, metalloproteins, vitamins, etc. It has been proposed that the antioxidant activity of plants may be due to their phenolic compounds $[47,48]$. These findings suggest that the phenolic content of TB plant is highly attributed to their antioxidant activity. 


\section{CONCLUSION}

Oxidative stress, caused by an imbalance between antioxidant systems and the production of oxidants (ROS), seems to be associated with various acute and chronic diseases. Fruits and vegetables which contain significant quantities of antioxidants are believed to have health benefits by counteracting oxidative stress thus reducing the risks of chronic diseases. The results revealed that plant extracts containing higher phenolic compounds showed maximum antioxidant activity. GC-MS analysis revealed the presence of various bioactive constituents in ethanolic extracts of TB plant parts which might be responsible for their antioxidant activity. The present study, for the first time, reports that seed of TB is a very effective $\mathrm{Fe}^{3+}$ chelator. The antioxidant activities of extracts of TB plant parts may be attributed to their strong hydrogen donating and metal chelation ability, reducing potential, effective hydroxyl and free radical scavenging activities. Overall, all tested parts of TB could be a potential source of natural antioxidants for food and pharmaceutical applications. Further studies may be focused on the mechanistic analysis of antioxidant and anti-inflammatory capacities of TB.

\section{ACKNOWLEDGEMENT}

Authors are grateful to Director CSIR-Indian Institute of Toxicology Research, Lucknow for providing the facilities for GC-MS analysis.

\section{CONFLICT OF INTERESTS}

The authors declare no conflict of interest

\section{REFERENCES}

1. Saraphanchotiwitthaya A, Ingkaninan K. Immunomodulatory activity of an acetone extract of Terminalia bellerica Roxb fruit on the mouse immune response in vitro. Int J Pharm Pharm Sci 2014;6:274-8.

2. Rashed K, Potocnjak I, Giacometti J. Terminalia bellerica aerial parts ethyl acetate extract exhibits antioxidant, antiinflammatory and anti-fibrotic activity in carbon tetrachloride intoxicated mice. J Funct Foods 2014;8:319-30.

3. Ghate NB, Hazra B, Sarkar R, Chaudhuri D, Mandal N. Alteration of bax/bcl-2 ratio contributes to Terminalia bellerica induced apoptosis in human lung and breast carcinoma. In Vitro Cell Dev Biol: Anim 2014;50:527-37.

4. Gupta R, Gupta A, Singh RL. Hepatoprotective activities of Triphala and its constituents. Int J Pharm Sci Rev Res 2015;4:34-55.

5. Shah CP, Santani DD. In vitro susceptibilities of human bacterial pathogens associated with dacryocystitis to Terminalia bellerica. Int J Curr Pharm Res 2011;3:32-3.

6. Das MS, Devi G. In vitro cytotoxicity and glucose uptake activity of fruits of Terminalia bellerica in vero, L-6 and 3T3 cell lines. J Appl Pharm Sci 2015;5:92-5.

7. Ali MS, Faruq KO, Islam A. Thrombolytic and cytotoxic activities of Terminalia bellerica Roxb. Bangladesh Pharm J 2013;16:131-5.

8. Gupta R, Singh RL, Singh P. Quantification of phytochemicals and evaluation of the antioxidant potential of ethanolic leaf extract of Terminalia bellerica, Terminalia chebula and Emblica officinalis vis-à-vis Triphala. Int J Pharm Sci Rev Res 2015;32:14-22.

9. Deb A, Sikha B, Biswajit D. Pharmacological activities of baheda (Terminalia bellerica): a review. J Pharmacogn Phytochem 2016;5:194-7.

10. Halliwell B, Aruoma OL. DNA damage by oxygen-derived species. FEBS Lett 1991;281:9-19.

11. Cadet J, Douki T, Ravanat JL. Oxidatively generated base damage to cellular DNA. Free Radical Biol Med 2010;49:9-21.

12. Sies H. Oxidative stress: oxidants and antioxidants. Exp Physiol 1997;82:291-5.

13. Sampath Kumara KK, Chethan J, Manasa N, Ashadevi J, Prakash H. Bioactive potential of herbaceous Phyllanthus species. Int J Pharm Pharm Sci 2012;4:457-61.

14. Ragazzi E, Veronese G. Quantitative analysis of phenolic compounds after thin layer chromatographic separation. J Chromatogr 1973;77:369-75.

15. Yen GC, Duh PD. Scavenging effect of methanolic extracts of peanut hulls on free radical and active oxygen. J Agric Food Chem 1994;42:629-32.
16. Nishikimi MN, Rao A, Yagi K. The occurrence of superoxide anion in the reaction of reduced phenazine methosulphate and molecular oxygen. Biochem Biophys Res Commun 1972;46;849-64.

17. Apati P, Szentmihalyi K, Kristo ST. Herbal remedies of Solidagocorrelation of phytochemical characteristics and antioxidative properties. J Pharm Biomed Anal 2003;32:1045-53.

18. Ohkaowa H, Ohisi N, Yagi K. Assay for lipid peroxides in animal tissues by thiobarbituric acid reaction. Anal Biochem 1979;95:351-8.

19. Halliwell B, Gutteridge JMC, Aruoma OI. The deoxyribose method: a simple test tube assay for the determination of rate constants for the reaction of hydroxyl radicals. Anal Biochem 1987; $165: 215-9$

20. Tsuda T, Watanabe M, Ohshima K, Yamamoto A, Kawakishi S, Osawa T. Antioxidative components isolated from the seed of tamarind (Tamarindus indica L.). J Agric Food Chem 1994;42:2671-4.

21. Mudiam MKR, Jain R, Dua VK, Singh AK, Sharma VP, Murthy RC. Application of ethyl chloroformate derivatization for solid phase microextraction gas chromatography-mass spectrometric determination of bisphenol-A in water and milk samples. Anal Bioanal Chem 2011;401:1695-701.

22. Singh BN, Singh BR, Singh RL. Polyphenolics from various extracts/fractions of red onion (Allium cepa) peel with potent antioxidant and antimutagenic activities. Food Chem Toxicol 2009a;47:1161-7.

23. Rahman $\mathrm{MH}$, Alam MH, Hossain MS, Jha MK, Islam A. Antioxidant, analgesic and toxic potentiality of methanolic extract of Stephania Japonica (Thunb.) Miers. leaf. Asian J Pharm Clin Res 2011;4:38-41.

24. Singh BN, Singh BR, Singh RL. Oxidative DNA damage protective activity, antioxidant and anti-quorum sensing potentials of Moringa oleifera. Food Chem Toxicol 2009b;47:1109-16.

25. Hazra B, Sarkar R, Biswas S, Mandal N. Comparative study of the antioxidant and reactive oxygen species scavenging properties in the extracts of the fruits of Terminalia chebula, Terminalia bellerica and Emblica officinalis. BMC Complementary Altern Med 2010;10:1-15.

26. Genwali GR, Acharya PP, Rajbhandari M. Isolation of gallic acid and estimation of total phenolic content in some medicinal plants and their antioxidant activity. Nepal J Sci Technol 2013;14:95-102.

27. Taso R, Deng Z. Separation procedures for naturally occurring antioxidant phytochemicals. J Chromatogr B: Anal Technol Biomed Life Sci 2004;812:85-99.

28. Singhal A, Nayak G, Budhwani A, Singhai A. 1, 1-diphenyl, 2 picryl hydrazyl radical scavenging activity of aqueous extract of Terminalia bellerica bark. Orient J Chem 2009;25:787-90.

29. Venkatalakshmi P, Brindha P, Induja K. In vitro antioxidant and antitumor studies on Terminalia catappa bark. Int J Pharm Pharm Sci 2014;6 Suppl 1:1-3.

30. Parejo I, Viladomat F, Bastida J, Schmeda-Hirschmann G, Burillo J, Codina C. Bioguided isolation and identification of the nonvolatile antioxidant compounds from fennel (Foeniculum vulgare Mill.) waste. J Agric Food Chem 2004;52:1890-7.

31. Jang LC, Jo EK, Bae SM. Antioxidant activity and fatty acid composition of four different persimmon seeds. Food Sci Technol Res 2010;16:577-84.

32. Chavan LV, Anita P, Naresh C. Antioxidant availability of Terminalia bellerica (Roxb.) in relation to its medicinal uses. Pharmacogn J 2010;2:338-44.

33. Majid H, Peter RC, Ronald BP, Robert TT. Antioxidant capacity of bioactive extracted from canola meal by subcritical water, ethanolic and hot water extraction. Food Chem 2009;114:717-26.

34. Tupe RS, Kemse NG, Khaire AA. Evaluation of antioxidant potentials and total phenolic contents of selected Indian herbs powder extracts. Int Food Res J 2013;20:1053-63.

35. Gulcin I, Koksal K, Elmastas M, Aboul-Enein HY. Determination of in vitro antioxidant and radical scavenging activity of Verbascum oreophilum C. Koch Var Joannis (Fam. Scrophulariaceae). Res J Biol Sci 2007;2:372-82.

36. Singh P, Vishwakarma SP, Singh RL. Antioxidant, oxidative DNA damage protective and antimicrobial activities of the plant Trigonellafoenum-graecum. J Sci Food Agric 2014;94:2497-504. 
37. Mahesh R, Nagulendran KR, Velavan S, Ramesh T, Begum VH. Studies on the antioxidative and free radical scavenging activities of myrobalan (Terminalia chebula retz) through various in vitro models. Pharmacologyonline 2007;2:1-11.

38. Del Rio D, Stewart AJ, Pellegrini N. A review of recent studies on malondialdehyde as toxic molecule and biological marker of oxidative stress. Nutr Metab Cardiovasc Dis 2005;15:316-28.

39. Marnett LJ. Lipid peroxidation-DNA damage by malondialdehyde. Mutat Res 1999;424:83-95.

40. Yeh RD, Chen JC, Lai TY, Yang JS, Yu CS, Chiang JH, et al. Gallic acid induces G0/G1 phase arrest and apoptosis in human leukemia HL-60 cells through inhibiting cyclin D and E and activating the mitochondria-dependent pathway. Anticancer Res 2011;31:2821-32.

41. Chandramohan Reddy T, Bharat Reddy D, Aparna A, Arunasree KM, Gupta G, Achari C, et al. Antileukemic effects of gallic acid on human leukemia K562 cells: down-regulation of COX-2, inhibition of BCR/ABL kinase and NF-KB inactivation. Toxicol In Vitro 2012;26:396-405.

42. Marnett LJ. Lipid peroxidation-DNA damage by malondialdehyde. Mutat Res 1999;424:83-95.

43. Kaur R, Arora S, Thukral AK. A report on antimutagenic and antioxidant activities of gallic acid. J Pharmacogn Phytochem 2015;3:173-8

44. Badhani B, Sharma N, Kakkar R. Gallic acid: a versatile antioxidant with promising therapeutic and industrial applications. RSC Adv 2015;5:27540-57.
45. Pero RW, Lund H, Leanderson T. Antioxidant metabolism induced by quinic acid: increased urinary excretion of tryptophan and nicotinamide. Phytother Res 2008;23:335-46.

46. Amala VE, Jeyaraj M. Comparative evaluation of photo components present in the methanolic extract of Terminalia chebula retz., Terminalia bellirica roxb. and Phyllanthus emblica l., fruit extracts using GC-MS analysis. Int J Pharm Biol Sci 2014;5:927-34.

47. Kumar KS, Ganesan K, Subba Rao PV. Antioxidant potential of solvent extracts of Kappaphycus alvarezii (Doty) doty: an edible seaweed. Food Chem 2008;107:289-95.

48. Dai J, Mumper RJ. Plant phenolics: extraction, analysis and their antioxidant and anticancer properties. Molecules 2010;15:7313-52.

49. Chen Y, Xiao H, Zheng J, Liang G. Structure-thermodynamicsantioxidant activity relationships of selected natural phenolic acids and derivatives: an experimental and theoretical evaluation. PLoS One 2015:10;e0121276.

\section{How to cite this article}

- Rasna Gupta, Ram Lakhan Singh, Neeraja Dwivedi. In vitro antioxidant activity and GC-MS analysis of the ethanolic extracts of Terminalia bellerica roxb (baheda). Int J Pharm Pharm Sci 2016;8(11):275-282. 